\title{
Reducing Nutrient and Irrigation Rates in Solar Greenhouse without Compromising Tomato Yield
}

\begin{abstract}
Shichao Wang, Xinlu Bai, Jianbin Zhou, and Zhujun Chen ${ }^{1}$ College of Natural Resources \& Environment/Key Laboratory of Plant Nutrition and the Agri-environment in Northwest China, Ministry of Agriculture, Northwest A\&F University, Yangling, Shaanxi 712100, China
\end{abstract}

Additional index words. formula fertilizer, irrigation, nutrient accumulation, solar greenhouse

\begin{abstract}
Overapplication of nutrients and water is common in intensive greenhouse systems. A 2-year experiment (2011-13) was conducted to study the effect of different nutrient and water treatments on the growth and yield of tomato (Lycopersicum esculentum Mill.) and on soil nutrient accumulations in solar greenhouses in South Loess Plateau, China. The treatments included 1) current fertilizer and water practices $(F W), 2)$ formula fertilizer and water 1 (FW1), 3) formula fertilizer and water 2 (FW2), and 4) farmer's practice (FP). Compared with FW, FW1 and FW2 had yields not significantly different from grower control treatments; however, they saved $35 \%$ to $46 \%$ of the nitrogen $(\mathrm{N})$ fertilizer, $40 \%$ to $54 \%$ of the phosphorus $\left(\mathrm{P}_{2} \mathrm{O}_{5}\right)$ fertilizer, $19 \%$ to $35 \%$ of the potassium $\left(\mathrm{K}_{2} \mathrm{O}\right)$ fertilizer, and $15 \%$ to $21 \%$ of irrigation water. The economic profits of FW1 and FW2 were greater than those of the FW and FP treatments. The two formula treatments also reduced soil electrical conductivity (EC) and the accumulation of nitrate, available $P$, and available $K$ in soil. However, the soil nutrients are still above optimal levels. Obvious $N$ surplus in the greenhouse was observed in different treatments, mainly because of high $\mathrm{N}$ input from manures. This study revealed there is great potential to reduce nutrient and water use while maintaining the same yield in a greenhouse system.
\end{abstract}

Vegetable production in protected production systems has developed rapidly since the 1980s in China. By 2011, the area of protected production in China reached 4 million ha $(\mathrm{Li}$ et al., 2013). Solar greenhouses are rectangular greenhouses 50 to $100 \mathrm{~m}$ long and 7 to $8 \mathrm{~m}$ wide, with one side wall $(\approx 3.6 \mathrm{~m}$ high $)$ and two end walls constructed from soil, brick, or concrete (Zhou et al., 2010). This is a common practice in protected production in northern China, which makes possible growing vegetables such as tomato, cucumber, and eggplant in the cold winter weather. Although solar greenhouses only account for $20 \%$ of the production area of protected agriculture in China, they produce nearly $40 \%$ of vegetables in north China (Zhang et al., 2011).

Solar greenhouses are a very intensive production system; growers make a good income compared with open-field production. However, growers usually add high amounts of organic and inorganic nutrients mainly because of 1 ) their traditional concept (the more fertilizers, the more crop yield) and

Received for publication 24 Aug. 2018. Accepted for publication 10 Dec. 2018.

This work was supported by the National Key Research and Development Program of China (2017YFD0200106), the National Natural Science Foundation of China (41201238), and the 111 Project (No.B12007).

S. Wang and X. Bai contributed equally to the manuscript.

${ }^{1}$ Corresponding author. E-mail: zjchen@nwsuaf. edu.cn.
2) poor services of rational fertilizer recommendations for small-hold farmers in China. Therefore, overuse of nutrients and water in the greenhouses is a common practice (Gao et al., 2012; Ren et al., 2014). Consequently, accumulations of nutrients in solar greenhouses are significant (Huang, 2011; Ju et al., 2006). Our recent study in the southern Loess Plateau of China showed that, even for the newly built solar greenhouses, where the topsoil was removed to build the walls of the greenhouse, the accumulation of nutrients was very fast as a result of the addition of manures and inorganic fertilizers (Gao et al., 2012).

The overaccumulation of nutrients in soil profiles results in a series of problems, including low nutrient use efficiency, poor product quality, and groundwater contamination (Chen et al., 2004; Shi et al., 2009). The apparent recovery rate of $\mathrm{N}$ fertilizer is usually less than $20 \%$ in greenhouses (Liu et al., 2008; Zhu et al., 2005). Nutrient imbalances in greenhouse soil resulting form high accumulation of $\mathrm{N}$, phosphorus $(\mathrm{P})$, and potassium $(\mathrm{K})$ also result in deficiencies in other nutrients, such as magnesium, and micronutrients (Chen et al., 2011). Overaccumulation of nitrate in the soil profile of greenhouses leads to nitrate leaching during the summer fallow period, when rainfall is high, which ultimately leads to nitrate concentration in groundwater (Ju et al., 2006; Zhou et al., 2010). Therefore, nutrient use efficiency in greenhouses is a concern, not only for crop production but also for the environment.

Overirrigation is another problem in solar greenhouses. The irrigation rates in some greenhouses ranged from 5000 to $9000 \mathrm{~m}^{3} \cdot \mathrm{ha}^{-1}$ in a growing season, which was several times greater than necessary to produce the crop being grown (Fan et al., 2014; Ren et al., 2010). Chen et al. (2013) found that deficit irrigation during the early stage of tomato crop production had no significant influence on crop yield and quality. Luo et al. (2014) reported that, compared with farmers' current water practices in the study region, reducing $40 \%$ of irrigation water got the same yield of mini watermelons. Overirrigation increases the leaching risk of nutrients from greenhouses (Fan et al., 2014). However, there are limited studies on the combined effects of nutrients and water on crop yields and soil nutrient contents in the solar greenhouse system.

Nutrient additions to cereal crops in China far exceed those in the United States and northern Europe, and much of the excess fertilizer is lost to the environment, degrading both air and water quality (Chen et al., 2014; Vitousek et al., 2009). Compared with cereals, overfertilization is more common in solar greenhouse production in China (Shi et al., 2009; Zhou et al., 2010). Therefore, we hypothesized there is the potential to optimize nutrient and water inputs in this system. To test our hypotheses, we compared the effects of different nutrient and water management practices on tomato yield and nutrient accumulation in the soil in solar greenhouses.

\section{Materials and Methods}

\section{Site description}

The study site was located in the southern edge of the Loess Plateau, Yangling, Shaanxi, China. It has a continental monsoon climate, with $630 \mathrm{~mm}$ average annual precipitation, and $12.9^{\circ} \mathrm{C}$ average annual air temperature.

The experiment was conducted in a farmer's greenhouse in Dazhai, Yangling, Shaanxi (lat. $34^{\circ} 17^{\prime} \mathrm{N}$, long. $108^{\circ} 2^{\prime} \mathrm{E}$ ), which is $90 \mathrm{~m}$ long and $6.5 \mathrm{~m}$ wide, and was built in 2010. The soil at the study site was an Anthrosol (World Reference Base for Soil Resources, WRB system). The soil has $10.7 \mathrm{~g} \cdot \mathrm{kg}^{-1}$ organic matter, $20.2 \mathrm{mg} \cdot \mathrm{kg}^{-1}$ inorganic $\mathrm{N}\left(\mathrm{NH}_{4}{ }^{+}-\mathrm{N}+\mathrm{NO}_{3}{ }^{-}-\mathrm{N}\right), 70.3 \mathrm{mg} \cdot \mathrm{kg}^{-1}$ Olsen-P, and $198 \mathrm{mg} \cdot \mathrm{kg}^{-1}$ available $\mathrm{K}$. The average air temperature in the greenhouse during crop season was $19.2{ }^{\circ} \mathrm{C}$.

\section{Experimental design}

The experiment was conducted over two growing seasons (Nov. 2011-Aug. 2012 and Nov. 2012-July 2013) in the same greenhouse mentioned previously. Three different fertilization and irrigation treatments were established in the greenhouse, including FW, FW1, and FW2. For the FW treatment, the irrigation and fertilization rates represented the average levels of the study region, which were from a survey we did in the region (Gao et al., 2012; Wang et al., 2015). The fertilization rates of the formula treatments were based on theoretical requirements of nutrients on desired tomato yield and initial soil nutrient content, and our research experience in the region (Gao et al., 2012; Luo et al., 2015). The experimental design was a randomized complete block with three replications. The plot area was $6.5 \times 5.5 \mathrm{~m}$ 
and each plot had six ridges, with a ridge distance of $70 \mathrm{~cm}$ and a row distance of $50 \mathrm{~cm}$. Tomato (cv. Jingpeng11) was planted in a single row on a ridge. Distance between plants was $30 \mathrm{~cm}$.

Our experimental plots covered half the area of the greenhouse. We also recorded the application rates of fertilizers and irrigation in the other half of the same greenhouse, where the farmer added water and fertilizer according to his experience (FP). The irrigation rate and fertilizer inputs for the different treatments for 2 years are given in Table 1 .
For the whole greenhouse, chicken manure was applied at the same rate, $112.5 \mathrm{t} \cdot \mathrm{ha}^{-1}(\mathrm{~N}=$ $1.19 \%$ ) in 2011 and $120 \mathrm{t} \cdot \mathrm{ha}^{-1}$ in 2012 . The basic physicochemical properties of manure were $280.3 \mathrm{~g} \cdot \mathrm{kg}^{-1}$ organic C, $11.9 \mathrm{~g} \cdot \mathrm{kg}^{-1}$ total $\mathrm{N}, 2.6 \mathrm{~g} \cdot \mathrm{kg}^{-1}$ total $\mathrm{P}$, and $18.0 \mathrm{~g} \cdot \mathrm{kg}^{-1}$ total $\mathrm{K} ; \mathrm{pH}$ was 7.40. All manure and $\mathrm{P}$ fertilizer (in superphosphate) were broadcast uniformly as a basal fertilizer on the surface, and then plowed into a 0 - to $20-\mathrm{cm}$ soil layer before transplanting tomatoes each year. The forms of $\mathrm{N}$ and $\mathrm{K}$ fertilizers used were urea and potassium sulfate.

Table 1. Irrigation rates and chemical fertilizer inputs from 2011 to 2013.

\begin{tabular}{lcc}
\hline Treatment & Irrigation rate $\left(\mathrm{m}^{3} \cdot \mathrm{ha}^{-1}\right)$ & $\begin{array}{c}\text { Chemical fertilizer inputs } \\
\mathrm{N}-\mathrm{P}_{2} \mathrm{O}_{5}-\mathrm{K}_{2} \mathrm{O}\left(\mathrm{kg}^{-1} \mathrm{ha}^{-1}\right)\end{array}$ \\
\hline $2011-12$ & & \\
$\quad$ Current practice & 3,045 & $542-622-580$ \\
Formula 1 & 2,600 & $353-376-467$ \\
Formula 2 & 2,400 & $291-285-375$ \\
Farmer' practice & 3,600 & $623-382-952$ \\
$2012-13$ & & \\
Current practice & 2,797 & $383-222-493$ \\
Formula 1 & 2,391 & $354-213-455$ \\
Formula 2 & 2,200 & $305-198-390$ \\
Farmer' practice & 3,300 & $336-214-681$ \\
\hline
\end{tabular}

About one-fourth of the total $\mathrm{N}$ inputs and onethird of the total $\mathrm{K}$ inputs for the current fertilizer and water practice, and one-sixth of the total $\mathrm{N}$ and $\mathrm{K}$ inputs for the formula treatments were applied as base fertilizer. A topdressing of $\mathrm{N}$ and $\mathrm{K}$ fertilizer was applied using the drip irrigation system (fertigation) five to seven times equally at 10 - to $15-\mathrm{d}$ intervals when the first fruit began expansion.

All plots were irrigated after transplanting with the same amount water: $25 \mathrm{~mm}$ in the 2011-12 season and $23 \mathrm{~mm}$ in the 2012-13 season. At 5 to $10 \mathrm{~d}$ after transplanting (DAT), the drip line was installed in each crop row in the greenhouse and the entire soil surface was covered with polyethylene film $(0.005 \mathrm{~mm}$ thick) to reduce soil evaporation and to increase the soil temperature. The drip switches were set up within drip lines to control the amount of irrigation and fertilizer received by each plot. A water flowmeter was set up on the main drip tape to record the irrigation amount for each cycle. The irrigation was five times during the whole tomato growing season. For all treatments, irrigation timing was done following local practice, which is irrigating
$\mathbf{A}$

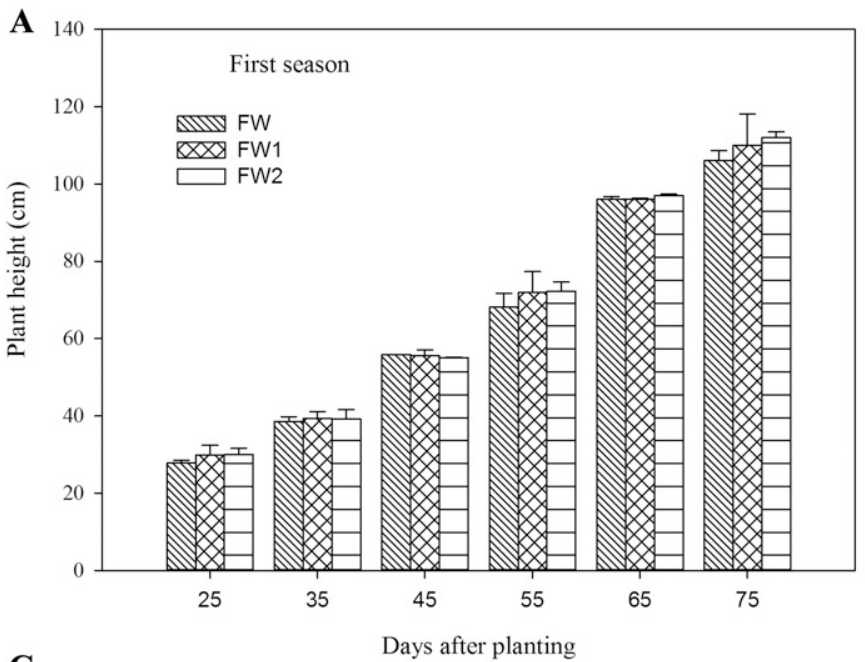

C

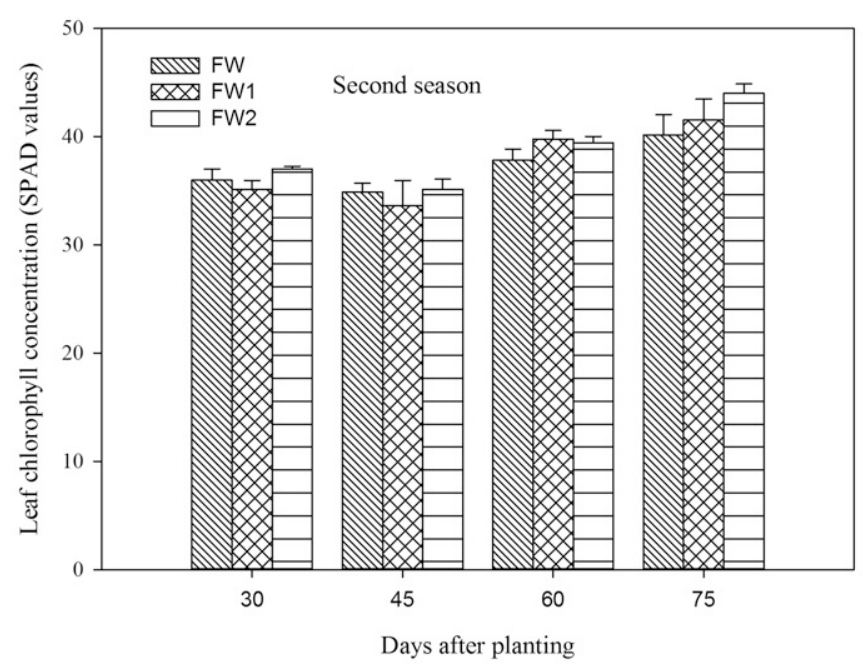

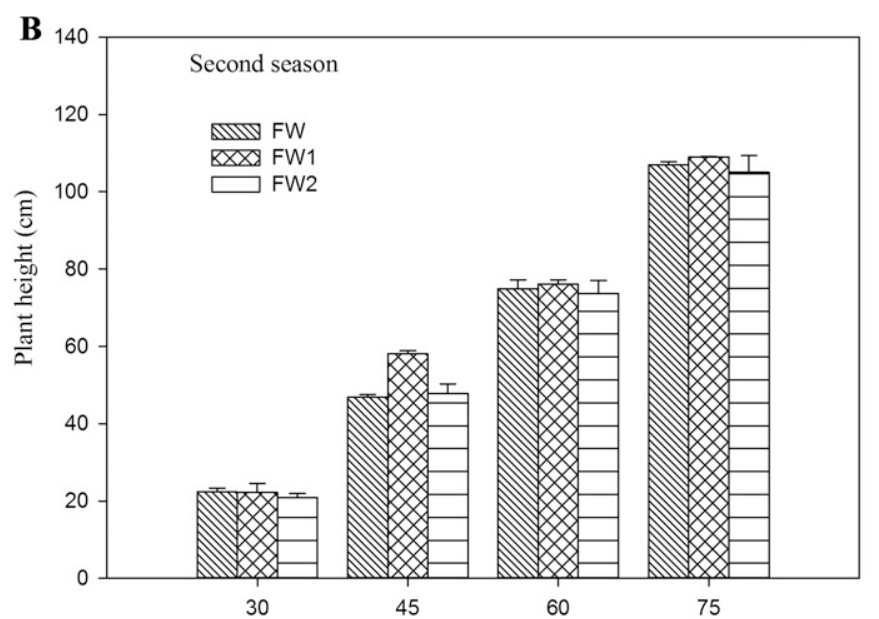

Days after planting

D

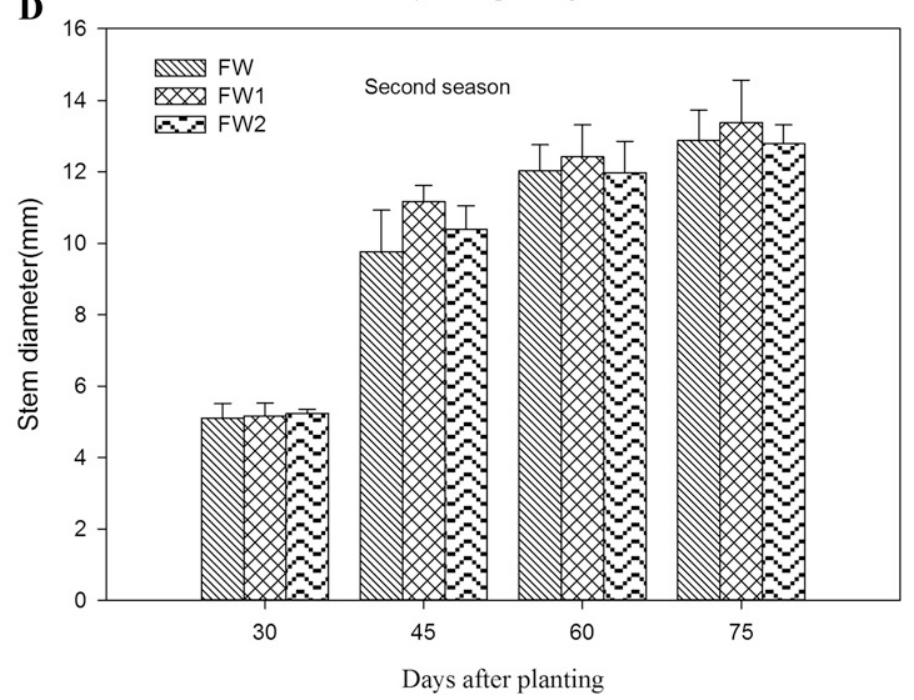

Fig. 1. Effect of different fertilization and water treatments on plant height, stem diameter, and chlorophyll content of tomato. Bars represent the sD of the mean ( $\mathrm{n}=3$ ). $\mathrm{BP}=$ before planting, $\mathrm{FW}=$ current fertilizer and water practice used by local farmers $(\mathrm{FW}), \mathrm{FW} 1=$ formula fertilizer and water-1, $\mathrm{FW} 2=$ formula fertilizer and water-2, and $\mathrm{FP}=$ farmer's practice. 
every 10 to $15 \mathrm{~d}$ after fruit expansion, depending on the climate and soil water content. There was no irrigation in January and December each year because of low temperatures.

During the experimental period, except for fertilizer and irrigation, other management practices such as pollination, pruning branches and stems, and pest control were the same for all treatments as local growers. Tomato seedlings were transplanted 7 Nov. 2011 and harvested on 8 Aug. 2012 in the first season, and transplanted 12 Nov. 2012 and harvested 25 July 2013 in the second season.

\section{Sampling and measurements}

Soil sampling and analytical methods. In 2011, before transplanting, topsoil samples (0$20 \mathrm{~cm}$ ) were taken from 10 soil cores in each plot. They were then mixed them to form one composite sample. After harvest, soil samples from two sites in each plot were collected from the top $200 \mathrm{~cm}$ of soil in $20-\mathrm{cm}$ increments.

Fresh soil samples were extracted with $1 \mathrm{~mol} \cdot \mathrm{L}^{-1} \mathrm{KCl}$ (soil:solution ratio, 1:10), then analyzed with an autoanalyzer (Bran Luebbe A3; SPW FLOW, Norderstedt, Germany) to determine the nitrate and ammonium $\mathrm{N}$ contents in the filtrate. Air-dried soil samples were ground and passed through $1-\mathrm{mm}$ and $0.25-\mathrm{mm}$ sieves for organic matter, total $\mathrm{N}$, available $\mathrm{P}$, available $\mathrm{K}$, and $\mathrm{EC}$ analyses. Soil organic matter (SOM) was determined using the Walkley-Black method (Nelson and Sommers, 1996). Total $\mathrm{N}$ was determined using the micro-Kjeldahl digestion, distillation, and titration method (Page et al., 1982). Soil-available P was measured using the method of Olsen et al. (1954). Available K content of the extract was determined by flame photometry. EC was determined in a 1:5 soil-water paste mixture with a conductivity meter (DDS-307A; Shanghai, China).

Sampling and measurement of plant sample. Six plants were chosen randomly

Table 2. Tomato yield and profit of different treatments in 2 years.

\begin{tabular}{|c|c|c|c|c|c|c|c|c|}
\hline \multirow[b]{2}{*}{ Growing season } & \multicolumn{4}{|c|}{ Tomato yield $\left(\mathrm{t} \cdot \mathrm{ha}^{-1}\right)$} & \multicolumn{4}{|c|}{ Economic profit $\left(\times 10^{3} \text { yuan } / \mathrm{ha}\right)^{2}$} \\
\hline & FW & FW1 & FW2 & FP & FW & FW1 & FW2 & FP \\
\hline $2011-12$ & $214 \pm 16$ & $219 \pm 7$ & $232 \pm 4$ & $210 \pm 7$ & 233 & 238 & 257 & 230 \\
\hline $2012-13$ & $223 \pm 7$ & $225 \pm 11$ & $226 \pm 14$ & $196 \pm 12$ & 242 & 245 & 247 & 216 \\
\hline
\end{tabular}

${ }^{\mathrm{z} E c o n o m i c ~ p r o f i t ~}=$ Tomato fruit income - Fertilizer costs

$\mathrm{FW}=$ current fertilizer and water practice used by local farmers; FW1 = formula 1, fertilizer and water; FW2 = formula 2, fertilizer and water; FP = farmer's practice.

A

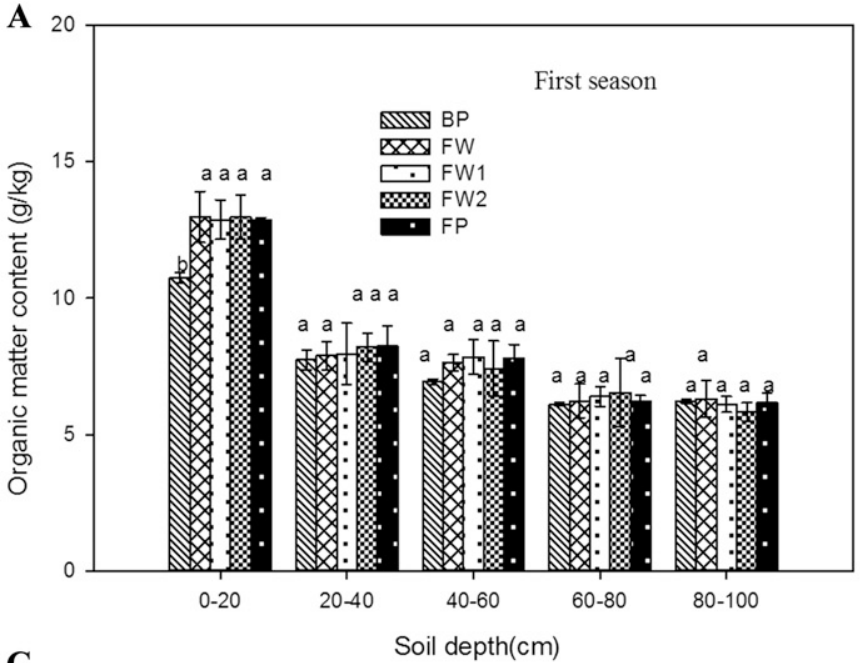

C

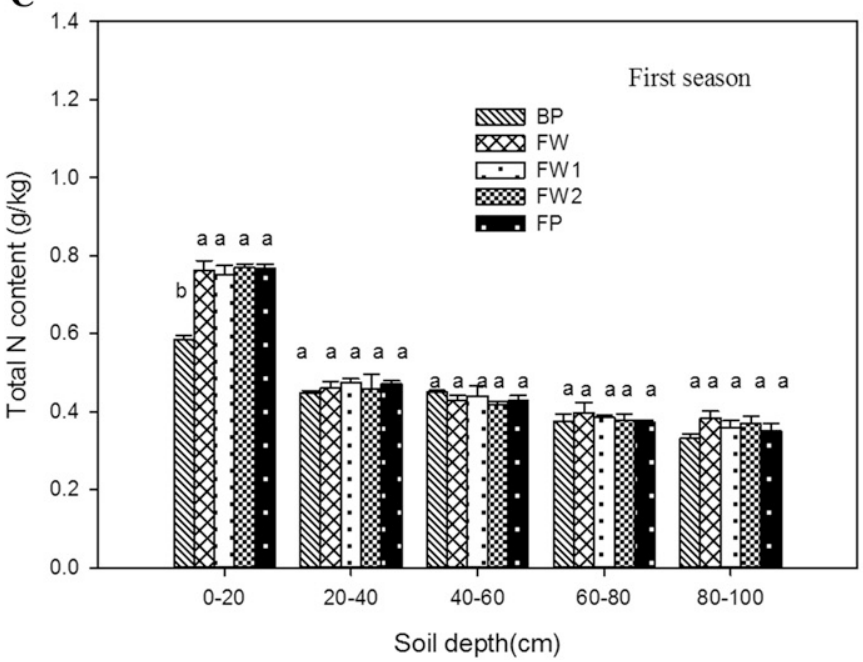

B

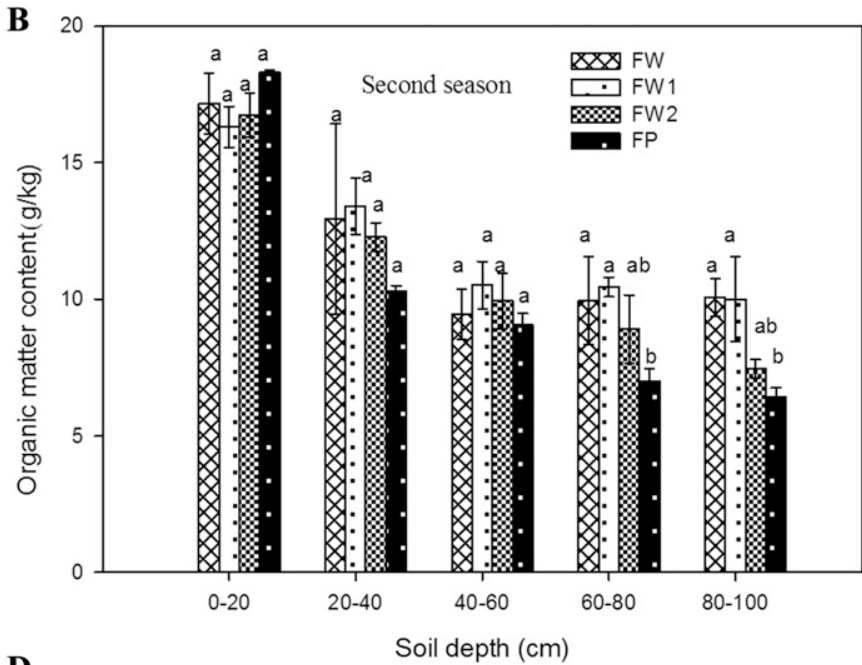

D

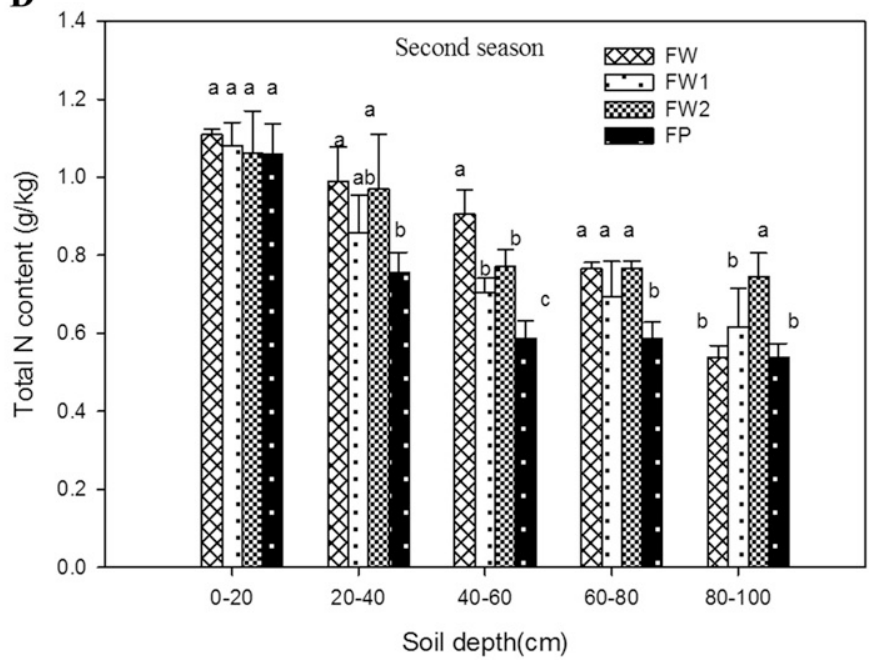

Fig. 2. Changes in soil organic matter and total $\mathrm{N}$ content at the 0 - to 100 -cm depth in the solar greenhouse during the two growing seasons. Bars represent the sD of the mean $(\mathrm{n}=3)$. The lowercase letters mean significant differences between treatments at $P<0.05$. BP $=$ before planting, FW $=$ current fertilizer and water practice used by local farmers $(\mathrm{FW}), \mathrm{FW} 1=$ formula fertilizer and water-1, FW2 = formula fertilizer and water-2, and $\mathrm{FP}=$ farmer's practice. 


\section{$\mathrm{NO}_{3}{ }^{-}-\mathrm{N}$ content $(\mathrm{mg} / \mathrm{kg})$}

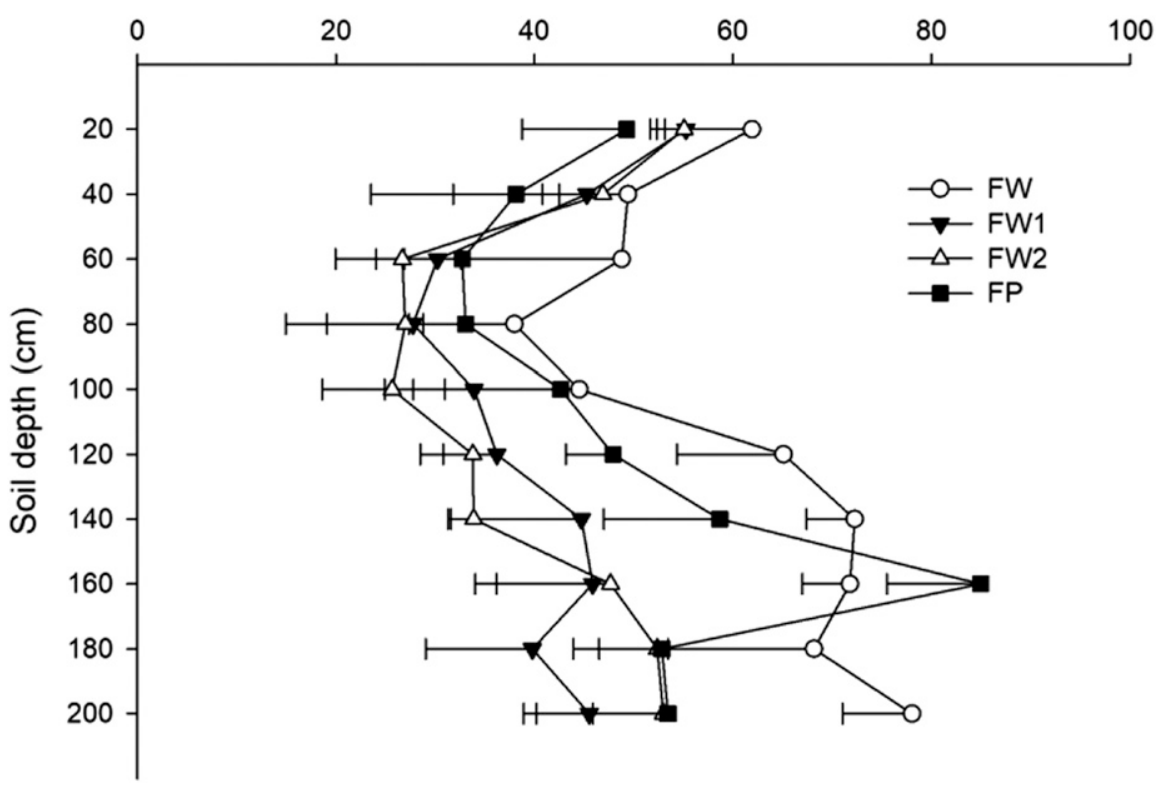

Fig. 3. Changes in soil $\mathrm{NO}_{3}{ }^{-}-\mathrm{N}$ content at the 0 - to $200-\mathrm{cm}$ depth in the solar greenhouse after harvesting the second crop. Bars represent the SD of the mean $(\mathrm{n}=3)$. $\mathrm{BP}=$ before planting, $\mathrm{FW}=$ current fertilizer and water practice used by local farmers $(\mathrm{FW}), \mathrm{FW} 1=$ formula fertilizer and water-1, FW2 = formula fertilizer and water-2, and FP = farmer's practice.

Table 3. Change in soil nitrate-N accumulation in the 0 - to $200-\mathrm{cm}$ soil depth in a greenhouse over 2 consecutive years.

\begin{tabular}{|c|c|c|c|c|}
\hline \multirow{2}{*}{$\begin{array}{l}\text { Soil } \\
\text { depth }(\mathrm{cm})\end{array}$} & \multirow[b]{2}{*}{ Sampling time } & \multirow[b]{2}{*}{ Treatments } & \multicolumn{2}{|c|}{$\mathrm{NO}_{3}{ }^{-}-\mathrm{N}$ accumulation $\left(\mathrm{kg} \cdot \mathrm{ha}^{-1}\right)$} \\
\hline & & & Accumulation $\pm \mathrm{SD}$ & Mean \\
\hline \multirow[t]{5}{*}{$0-100$} & BP & $\mathrm{BP}$ & $105.8 \pm 19.6$ & $105.8 \pm 19.6 \mathrm{~B}$ \\
\hline & After harvesting the second season & FW & $619.2 \pm 129.1 \mathrm{a}$ & $523.5 \pm 68.8 \mathrm{~A}$ \\
\hline & & FW1 & $489.7 \pm 43.5 \mathrm{a}$ & \\
\hline & & FW2 & $461.6 \pm 56.1 \mathrm{a}$ & \\
\hline & & FP & $515.2 \pm 121.1$ & \\
\hline \multirow[t]{5}{*}{$0-200$} & BP & BP & $174.6 \pm 7.2$ & $174.6 \pm 7.2 \mathrm{~B}$ \\
\hline & After harvesting the second season & FW & $1,486.3 \pm 226.3 \mathrm{a}$ & $1,164.5 \pm 230.9 \mathrm{~A}$ \\
\hline & & FW1 & $1,007.1 \pm 127.5 \mathrm{a}$ & \\
\hline & & FW2 & $999.9 \pm 129.1 \mathrm{a}$ & \\
\hline & & FP & $1,242.0 \pm 25.7 \mathrm{a}$ & \\
\hline
\end{tabular}

The mean is the average of nitrate- $\mathrm{N}$ in three irrigation and fertilizer treatments. The lowercase letters mean there was a significant difference between treatments at $P<0.05$.

$\mathrm{BP}=$ before planting; $\mathrm{FW}=$ current fertilizer and water practice used by local farmers; $\mathrm{FW} 1=$ formula 1 , fertilizer and water; FW2 = formula 2, fertilizer and water; FP = farmer's practice.

from each plot to measure plant height, stem diameter, and chlorophyll content in leaves [using a soil-plant analyses development (SPAD) chlorophyll meter (SPAD-502Plus; Minolta, Japan)] once every 10 d 25 DAT. Nine tomato leaves were chosen from the top, middle, and bottom of the plant to measure chlorophyll content. Plant height was measured in both years. Only SPAD of leaves and diameters of stems were measured the second year. Fresh yield, individual fruit weight, and fruit number in each plot were measured at each harvest during both seasons. The fruit harvesting period in the first season was from 18 Mar. 2011 to 1 Aug. 2012, and from 24 Feb. 2012 to 23 July 2013 in the second season. The total marketable yield of each plot was calculated.

Subsamples of tomato fruit were ovendried at $65^{\circ} \mathrm{C}$ for at least $72 \mathrm{~h}$ after harvest- ing. After harvesting, five plants from each plot were taken and divided into leaves, stems, and roots; weighed before and after drying at $65{ }^{\circ} \mathrm{C}$ for $48 \mathrm{~h}$; and then sieved through a $0.5-\mathrm{mm}$ mesh. Total $\mathrm{N}$ in the fruit, leaves, stems, and roots was determined using the Kjeldahl method.

\section{Calculation of $\mathbf{N}$ balances and economic profit}

Apparent $N$ balance. The $\mathrm{N}$ balance of each treatment was calculated by subtracting the gross $\mathrm{N}$ inputs from the gross $\mathrm{N}$ outputs. The gross inputs consisted of $\mathrm{N}$ derived from manure and inorganic fertilizers, irrigation, and soil inorganic $\mathrm{N}$ in the 0 - to $60-\mathrm{cm}$ soil layer at the beginning of the experiment. $\mathrm{N}$ input from inorganic $\mathrm{N}$ fertilizer and manure was calculated by multiplying the fertilizer or manure application rates by their $\mathrm{N}$ contents. $\mathrm{N}$ input from irrigation water was estimated by multiplying the irrigation rates by $\mathrm{N}$ content $(\mathrm{He}$ et al., 2007; Zhou et al., 2006).

Gross $\mathrm{N}$ output refers to the $\mathrm{N}$ removal by the crop and inorganic $\mathrm{N}$ in the 0 - to $60-\mathrm{cm}$ soil layer after harvesting the second crop. $\mathrm{N}$ uptake by crop was calculated based on multiplying the economic yield of tomato by its $\mathrm{N}$ uptake parameter (Huang, 2011). It included the total $\mathrm{N}$ in the aboveground of crop (including fruits). Nutrient losses resulting from leaching were not included in the calculation of gross output because of less water infiltration in the greenhouse soil under the relatively closed environment.

Economic profit. The economic profit of each treatment was calculated by subtracting the gross income from the gross expense. The gross income was calculated by multiplying the economic fruit yield of each plot and market prices at different harvest times. The gross expense only considered fertilizer and manure costs, and was calculated by multiplying the applied fertilizer rates with their prices.

Statistical analysis. Analyses of variance (ANOVA) for all data was performed using the SAS statistical program (SAS version 8.1). Whenever ANOVA detected significant differences between treatments, mean separation was conducted using the least significant difference test at $P<0.05$. All figures were plotted using Sigmaplot version 12.0.

\section{Results}

Tomato growth and fruit yield. Treatments had no significant effects on tomato plant height, stem diameter, and SPAD values during the different growing seasons (Fig. 1). Fruit yields also did not show significant differences resulting from treatments in both seasons (Table 2). The economic profits of FW1 and FW2 were greater than those of the FW and FP treatments.

SOM and total $N$. There were no significant differences in SOM content in the topsoil $(0-20 \mathrm{~cm})$ between treatments in either growing season. The SOM content of the subsoil $(20-60 \mathrm{~cm})$ was relatively stable. Compared with SOM content before planting, the average SOM content in the first and second seasons was increased by $22 \%$ and $45 \%$, respectively (Fig. $2 \mathrm{~A}$ and B).

Total $\mathrm{N}$ content in the topsoil after the first or second growing season $\left(0.76\right.$ and $\left.1.08 \mathrm{~g} \cdot \mathrm{kg}^{-1}\right)$ was significantly greater than before planting $\left(0.59 \mathrm{~g} \cdot \mathrm{kg}^{-1}\right)$ (Fig. $2 \mathrm{C}$ and D), equivalent to an increase of $29 \%$, up to $83 \%$. Total $\mathrm{N}$ in subsoil $(20-100 \mathrm{~cm})$ was less than in topsoil; it increased continually over two seasons. Total soil $\mathrm{N}$ increased during the second season compared with the first season; however, it did not change significantly for different treatments.

Soil nitrate. The soil nitrate content at the end of the second season was consistently greater in the $\mathrm{FW}$ treatment compared with the other treatments (FW1, FW2, and FP), except at a soil depth of 160 to 200 (Fig. 3). Nitrate content at a soil depth of 0 to $40 \mathrm{~cm}$ was greater for FW1 and FW2 compared with 


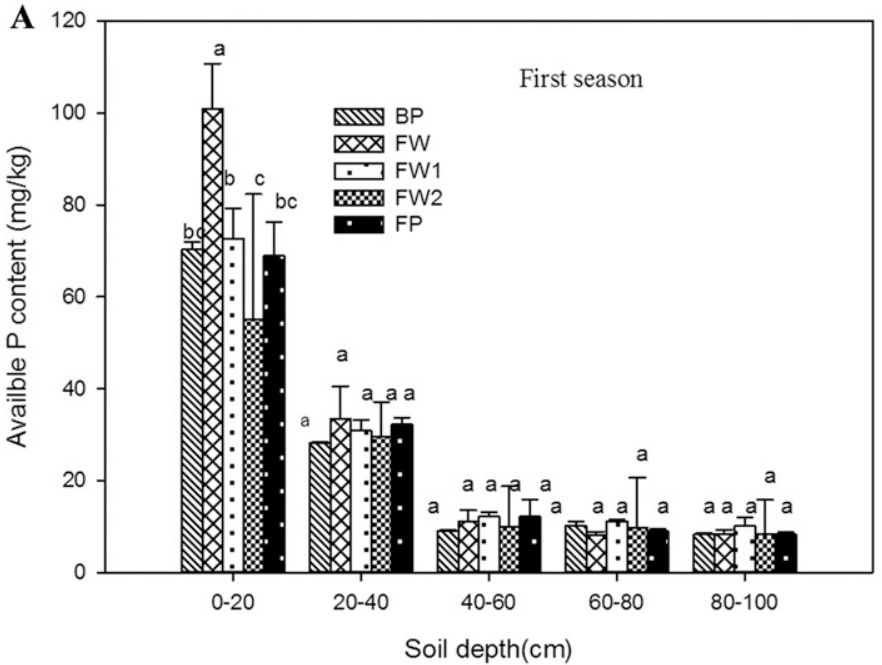

C

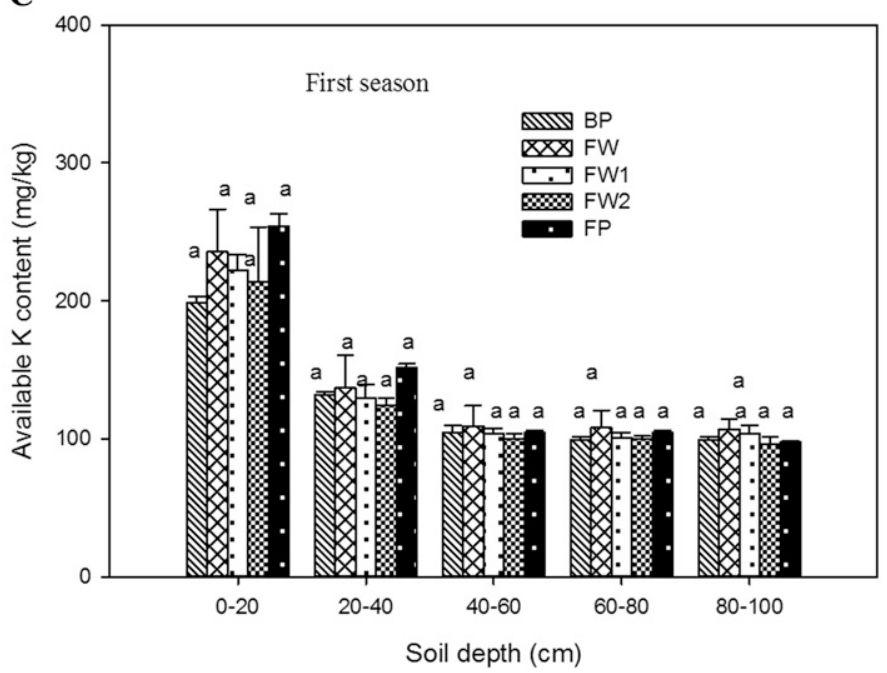

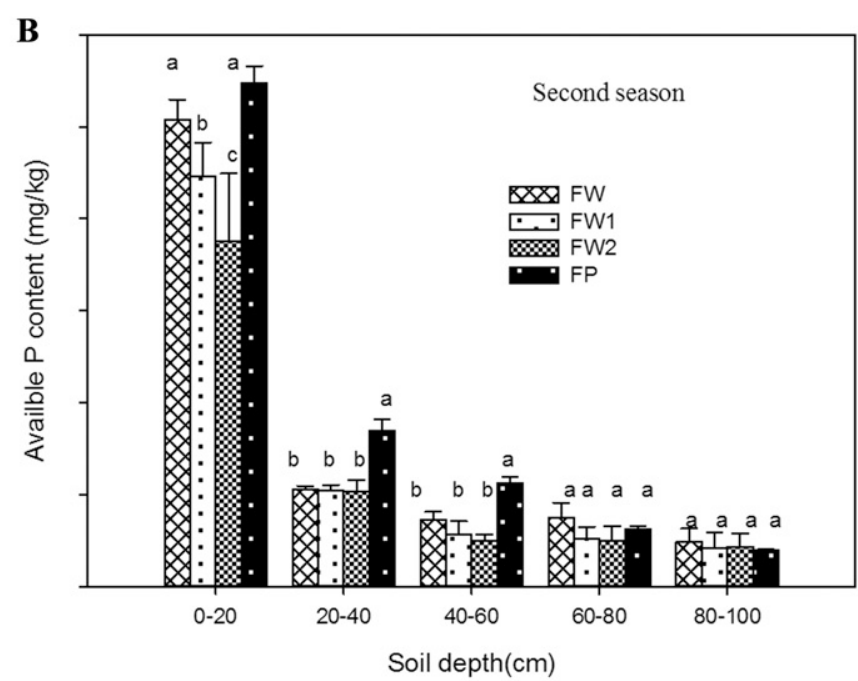

D

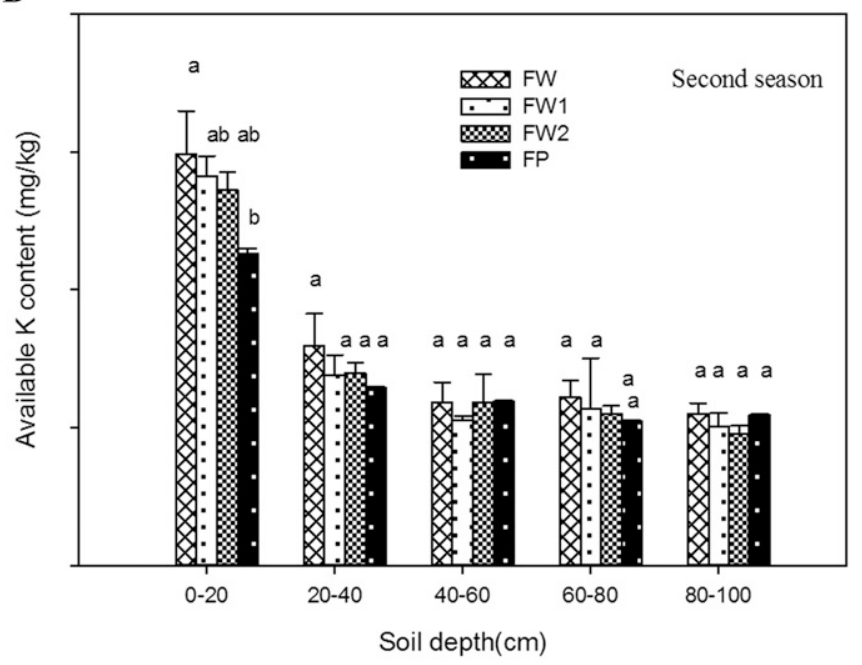

Fig. 4. Changes in soil-available $\mathrm{P}$ and available $\mathrm{K}$ content at the 0 - to $100-\mathrm{cm}$ depth in the solar greenhouse during the two growing seasons. Bars represent the SD of the mean $(\mathrm{n}=3)$. The lowercase letters mean significant differences between treatments at $P<0.05 . \mathrm{BP}=$ before planting, $\mathrm{FW}=\mathrm{current}$ fertilizer and water practice used by local farmers $(\mathrm{FW}), \mathrm{FW} 1=$ formula fertilizer and water-1, FW2 $=$ formula fertilizer and water-2, and FP $=$ farmer's practice.

FP, but was significantly less at the 60- to 200-cm depth (Fig. 3).

Compared with FW, soil nitrate-N accumulation at the 0 - to $200-\mathrm{cm}$ soil depth was less by $32.4 \%$ and $32.8 \%$ in FW 1 and FW2, respectively. The average nitrate-N accumulation at depths of 0 to $100 \mathrm{~cm}$ $\left(523.5 \mathrm{~kg} \cdot \mathrm{ha}^{-1}\right)$ and 0 to $200 \mathrm{~cm}(1164.4$ kg.ha) after harvesting the second crop were significantly greater compared with the nitrate- $\mathrm{N}$ accumulation before planting (Table 3).

Soil-available $P$ and $K$. At the end of the first growing season, available $P$ in the topsoil $(0-20 \mathrm{~cm})$ was significantly greater in the FW treatment compared with the available $\mathrm{P}$ at the start of the study and the FW1, FW2, and FP treatments (Fig. 4A). Available P in the FW2 treatment was less than the FW1 and FP treatments both in the first and second seasons (Fig. 4A and B). The average available $\mathrm{P}$ in the topsoil of the second season was greater than that in the first season (Fig. 4B).

In the first season, there was no significant difference between treatments in available $\mathrm{K}$ content across all soil depths (Fig. 4C). In the second season, there were significant differences between treatments in available $\mathrm{K}$ content in the topsoil only (Fig. 4D). Compared to the first season, the increasing available $\mathrm{K}$ content in the second season ranged from $26.8 \%$ to $27.5 \%$.

Electrical conductivity. In the first season, $\mathrm{EC}$ in the topsoil differed significantly between treatments; FW had the greatest EC compared with the EC before planting (Fig. 5Fig.). EC in the $\mathrm{FW}$ treatment was $134 \%$ greater than the $\mathrm{EC}$ before planting. The EC in the FW1 and FW2 treatments was $70 \%$ and $47 \%$ greater, respectively, than the EC before planting. After the second season of the experiment, there were no significant differences in EC in the different treatments in the topsoil. With the exception of the soil EC at a depth of 60 to 80 $\mathrm{cm}$, soil EC in subsoil of FP was significantly greater than that of FW1 and FW2 (Fig. 5B).

Apparent $N$ balance in two seasons. $\mathrm{N}$ from manure contributed more than twothirds of the total $\mathrm{N}$ input in the different treatments (Table 4). Total $\mathrm{N}$ inputs for the treatments were greater than $\mathrm{N}$ removal in crops; therefore, an obvious $\mathrm{N}$ surplus was observed in the different treatments. Apparent $\mathrm{N}$ surpluses were $3238,3028,2901$, and $3281 \mathrm{~kg} \cdot \mathrm{ha}^{-1}$ for the FW, FW1, FW2, and FP treatments, respectively.

\section{Discussion}

Effects of reducing nutrient and irrigation rate on tomato yield. The FW1 and FW2 treatments had yields not significantly different from grower control treatments; however, they saved $35 \%$ to $46 \%$ of the $\mathrm{N}$ fertilizer, $40 \%$ to $54 \%$ of the $\mathrm{P}$ fertilizer, and $19 \%$ to $35 \%$ of the $\mathrm{K}$ fertilizer. Economic profits with FW1 and FW2 treatments were high because of the reduction in the fertilizer input. Other studies also reported that high $\mathrm{N}$ input for vegetables grown in greenhouses did not increase yield significantly. However, it decreased farmers' returns as a result of high fertilizer inputs (Zhang et al., 2012; Zhou et al., 2006). Fertilizer consumption in China has increased strongly in past decades, and growth is mainly 

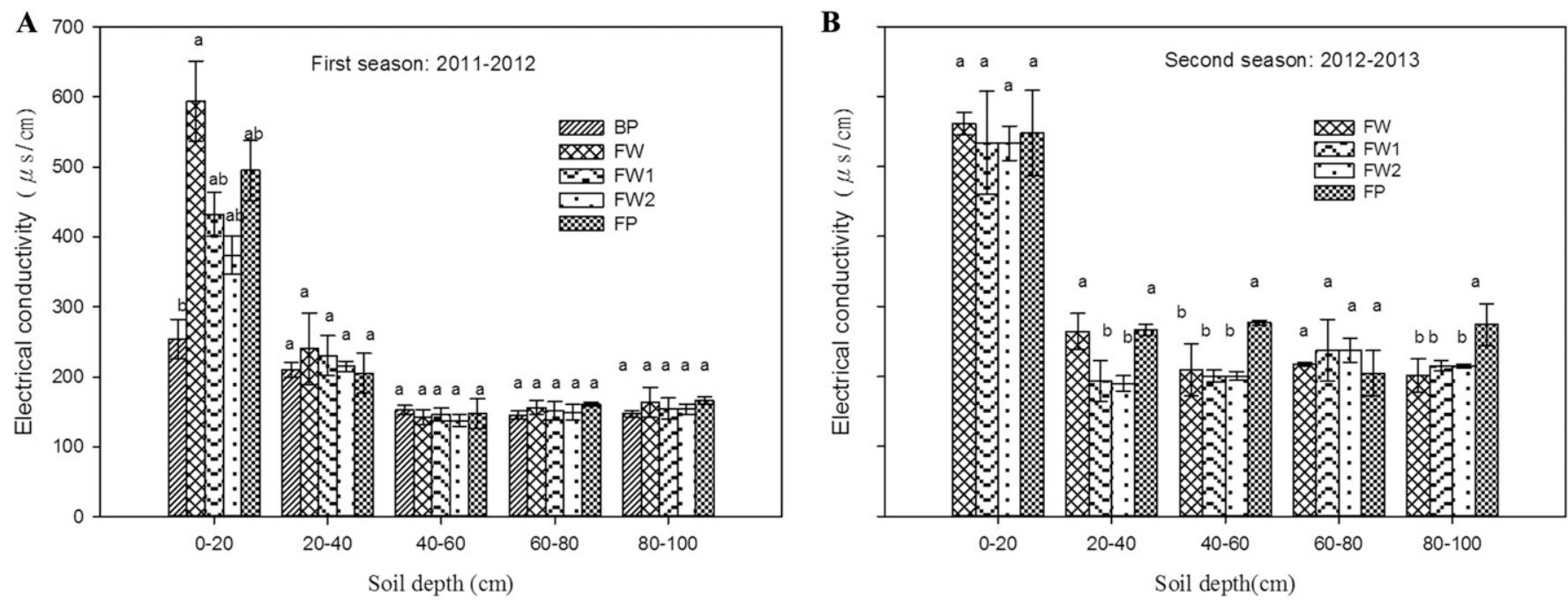

Fig. 5. Changes in soil electrical conductivity (EC) of the 0 - to $100-\mathrm{cm}$ depth in solar greenhouse during the two growing seasons. Bars represent the sD of the mean $(\mathrm{n}=3)$. The lowercase letters mean significant differences between treatments at $P<0.05 . \mathrm{BP}=$ before planting, $\mathrm{FW}=$ current fertilizer and water practice used by local farmers (FW), FW1 = formula fertilizer and water-1, FW2 = formula fertilizer and water-2, and FP = farmer's practice.

Table 4. Nitrogen balance (measured in kilograms per hectare) in the solar greenhouse across the two growing seasons.

\begin{tabular}{|c|c|c|c|c|}
\hline Inputs and outputs & FW & FW1 & FW2 & FP \\
\hline \multicolumn{5}{|l|}{$\mathrm{N}$ input } \\
\hline (2) Fertilizer-N & 925 & 707 & 596 & 959 \\
\hline (3) Soil N $(0-60 \mathrm{~cm})$ before sowing & 18.8 & 18.8 & 18.8 & 18.8 \\
\hline Total input $=[(1)+(2)+(3)+(4)]$ & $3,727.8$ & $3,509.0$ & $3,397.6$ & $3,762.8$ \\
\hline \multicolumn{5}{|l|}{$\mathrm{N}$ output } \\
\hline (5) $\mathrm{N}$ removal in crop & 394.8 & 403.9 & 424.1 & 410.8 \\
\hline
\end{tabular}

$\mathrm{FW}=$ current fertilizer and water practice used by local farmers; FW1 $=$ formula 1, fertilizer and water; FW2 $=$ formula 2 , fertilizer and water; FP $=$ farmer's practice.

attributable to fertilizer consumption in horticultural crops, including vegetables and fruit trees (Xin et al., 2012). Therefore, our study indicates that there is a great potential to reduce nutrient inputs in solar greenhouse in China while maintaining the same yield as the current production system. An intensive study showed that when advanced crop and nutrient management was used, it increased average cereal yields without any increase in $\mathrm{N}$ fertilizer at different agroecological areas in China (Chen et al., 2014). Further study is needed to compare different nutrient management practices on vegetable production in different areas in China.

Compared with FW, the FW1 and FW2 treatments also saved $15 \%$ to $21 \%$ of irrigation water. And they save more water comparing with FP (Table 1). Another study by our group at a different site found that reducing $40 \%$ of irrigation water from $\mathrm{FW}$ did not reduce tomato yield, and it increased use efficiency of irrigation water by $50.9 \%$ (Luo et al., 2015). Other studies showed that when water inputs were decreased, tomato yield increased (Chen et al., 2013; Fan et al., 2014). This indicates there is also a potential to save irrigation water in greenhouse production.

Effects of reducing nutrient and water rates on nutrients in greenhouse soils. Compared with FW, the two formula treatments reduced the accumulations of available nutrients in the soil. This result is in agreement with previous reports by other researchers (Zhao et al., 2011; Zhou et al., 2006). However, soil nutrient contents are still at a relatively high level. The average soil-available P content is within the medium category, according to Gao et al. (2012); the average available $\mathrm{K}$ content is within the high category, according to Huang (2011).

Although we decreased inputs of chemical fertilizers during the second season, soil-available $\mathrm{P}$ and $\mathrm{K}$ contents were still increased (Fig. 4). This was attributed to the high addition of manure in the greenhouse. Compared with the arable land, the application of different manures is very common in greenhouses (Zhou et al., 2010). However, farmers in China usually do not consider the nutrients from manures in their practice. One reason is that it is very complex for them to estimate the available nutrients from the different manures. Therefore, developing an easy method to evaluate the nutrient release from manures is needed to make optimal fertilizer recommendation for this system.

$N$ balance in greenhouse soil. In our study, there were no significant differences in total $\mathrm{N}$ uptake between the different treatments. Furthermore, high $\mathrm{N}$ application decreased $\mathrm{N}$ uptake by the vegetables (Table 4). This confirms the overapplication of $\mathrm{N}$ in the greenhouse system. Nutrient balance analysis showed an $\mathrm{N}$ surplus in the different treatments (Table 4). Although we reduced inorganic $\mathrm{N}$ fertilizer inputs in our two formula treatments, the $\mathrm{N}$ surplus was still very high as a result of the high proportion of $\mathrm{N}$ input from manure. Other studies also reported that manure accounted for more than $50 \%$ of the $\mathrm{N}$ applied to greenhouse soils in greenhouses in other regions (Chen et al., 2004; Yu et al., 2010). If one-third of total $\mathrm{N}$ in manure is available for crops during the first season (Defra, 2010), it seems that available $\mathrm{N}$ from manure could meet the plant demand. Therefore, ignoring $\mathrm{N}$ from manures also explains the $\mathrm{N}$ surplus in the greenhouse.

Compared with $\mathrm{P}$ and $\mathrm{K}$ in soil, $\mathrm{N}$ has different loss pathways from soil. $\mathrm{N}$ saturation in an ecosystem increases its losses to the environment (Chen et al., 2014). Our two formula treatments reduced nitrate-N in the 0 - to 200 -cm soil layers by $5 \%$ to $32 \%$. Similar results have been reported by others (Min et al., 2012; Sun et al., 2013; Zhang et al., 2007). Compared with open fields, solar greenhouses have high temperatures, and organic matter in soil is also high. Therefore, $\mathrm{N}$ 
surplus in greenhouse soil could also increase its gaseous loss. More research is needed to estimate the loss by different pathways.

\section{Conclusions}

Current results indicate that, compared with the FW, the two formula treatments gave similar tomato yields; however, they conserved nutrients and water. And although they reduced the accumulation of available nutrients in the soil, the nutrient levels in the soil were still above optimal levels. This confirms that the overapplication of fertilizer and irrigation is very severe in the greenhouse production system considered here. Our results reveal the potential to reduce the current overapplication of nutrients and water in the greenhouse production system. We recommend that growers in the study region reduce nutrient and water inputs in their greenhouses.

\section{Literature Cited}

Chen, Z.J., J.J. Gao, W.Y. Zhao, C.Y. Wang, and J.B. Zhou. 2011. Effects of application of phosphorus and potassium fertilizers on ion compositions of soil solution in solar greenhouse. Transactions of the CSAE 27:261266.

Chen, J.L., S.Z. Kang, T.B. Du, R.J. Qiu, P. Gup, and R.Q. Chen. 2013. Quantitative response of greenhouse tomato yield and quality to water deficit at different growth stages. Agr. Water Mgt. 129:152-162.

Chen, Q., X.S. Zhang, H.Y. Zhang, P. Christie, X.L. Li, D. Horlacher, and H.P. Liebig. 2004. Evaluation of current fertilizer practice and soil fertility in vegetable production in the Beijing region. Nutr. Cycl. Agroecosyst. 69:51-58.

Chen, X.P., Z.L. Zui, M.S. Fan, P. Vitousek, M. Zhao, W.Q. Ma, and Z.L. Wang. 2014. Producing more grain with lower environmental costs. Nature 514:486-489.

Defra. 2010. Fertilizer manual (RB209). TSO, Norwich, UK.

Fan, Z.B., S. Lin, X.M. Zhang, Z.M. Jiang, K.C. Yang, D.D. Jian, Y.Z. Chen, J.L. Li, and J.G. Wang. 2014. Conventional flooding irrigation causes an overuse of nitrogen fertilizer and low nitrogen use efficiency in intensively used solar greenhouse vegetable production. Agr. Water Mgt. 144:11-19.

Gao, J.J., X.L. Bai, B. Zhou, J.B. Zhou, and Z.J. Chen. 2012. Soil nutrient content and nutrient balances in newly-built solar greenhouses in northern China. Nutr. Cycl. Agroecosyst. 94:63-72.

He, F.F., Q. Chen, R.F. Jiang, and X.P. Chen. 2007. Yield and nitrogen balance of greenhouse tomato (Lycopersicum esculentum Mill.) with conven- tional and site-specific nitrogen management in northern China. Nutr. Cycl. Agroecosyst. $77: 1-14$.

Huang, D.M. 2011. Fertilizer technique of vegetables. China Agriculture Press, Beijing, China.

Ju, X.T., C.L. Kou, F.S. Zhang, and P. Christie. 2006. Nitrogen balance and groundwater nitrate contamination: Comparison among three intensive cropping systems on the North China Plain. Environ. Pollut. 143:117-125.

Li, J., J.M. Li, K. Cao, Z.H. Zhao, D.L. Zhang, F. Xu, H.B. Du, and X.Q. Jiang. 2013. Present status and existing problems of studies on protected agriculture in Northwest China. Zhongguo Shucai 6:24-29.

Liu, Z.H., L.U. Jiang, and W.J. Zhang. 2008. Evolution of fertilization rate and variation of soil nutrient contents in greenhouse vegetable cultivation in Shangdong. Turang Xuebao 45:296-303.

Luo, Q., Z.J. Chen, J.F. Lei, Y.L. Liu, and J.B Zhou. 2014. Effects of reducing water and fertilizer on yield, quality of mini-watermelon and soil moisture in solar greenhouse. Northern Hort. 9:48-53.

Luo, Q., Z.J. Chen, B. Yan, J.F. Lei, X.M. Zhang, X.L. Bai, and J.B. Zhou. 2015. Effects of reducing water and fertilizer rates on soil moisture and yield and quality of tomato in solar greenhouse. J. Plant Nutrient Fertilizer 21:449-457.

Min, J., H. Zhang, and W. Shi. 2012. Optimizing nitrogen input to reduce nitrate leaching loss in greenhouse vegetable production. Agr. Water Mgt. 111:53-59.

Nelson, D.W. and L.E. Sommers. 1996. Total carbon, organic carbon, and organic matter, $\mathrm{p}$ 961-1010. In: D.L. Sparks (ed.). Methods of soil analysis, part 3: Chemical methods. 5th ed. SSSA Book, Madison, WI.

Olsen, S.R., C.V. Cole, F.S. Watanable, and L.A. Dean. 1954. Estimation of available phosphorus in soil by extraction with sodium bicarbonate. USDA circular no. 939. USDA, Washington, DC.

Page, A.L., R.H. Miller, and D.R. Keeney. 1982 Methods of soil analysis, part 3: Chemical methods. 5th ed. SSSA Book, Madison, WI.

Ren, T., P. Christie, J.G. Wang, Q. Chen, and F.S Zhang. 2010. Root zone soil nitrogen management to maintain high tomato yields and minimize nitrogen losses to the environment. Scientia Hort. 125:25-33.

Ren, T., J.G. Wang, Q. Chen, F.S. Zhang, and S.C. Lu. 2014. The effects of manure and nitrogen fertilizer applications on soil organic carbon and nitrogen in a high-input cropping system. PLoS One 9:1-11.

Shi, W.M., J. Yao, and F. Yan. 2009. Vegetable cultivation under greenhouse conditions leads to rapid accumulation of nutrient, acidification and salinity of soils and groundwater contamination in South-Eastern China. Nutr. Cycl. Agroecosyst. 83:73-84.

Sun, Y., K. Hu, Z. Fan, Y. Wei, S. Lin, and J. Wang. 2013. Simulating the fate of nitrogen and optimizing water and nitrogen management of greenhouse tomato in North China using the EU-Rotate_N model. Agr. Water Mgt. 128:72-84.

Vitousek, P.M., R. Naylor, T. Crews, M.B. David, L.E. Drinkwater, E. Holland, P.J. Johnes, J. Katzenberger, L.A. Martinelli, P.A. Matson, G. Nziguheba, D. Ojima, C.A. Palm, G.P. Robertson, P.A. Sanchez, A.R. Townsend, and F.S. Zhang. 2009. Nutrient imbalances in agricultural development. Science 324:1519-1520.

Wang, S.C., X.L. Bai, Z.J. Chen, and J.B. Zou. 2015. Nutrient balance and accumulation in soils of solar greenhouses. Research of Environmental Science 28:1091-1098.

Xin, L.J., X.B. Li, and M.H. Tai. 2012. Temporal and regional variations of China's fertilizer consumption by crops during 1998-2008. J. Geogr. Sci. 22:643-652.

Yu, H.Y., T.X. Li, and X.Z. Zhang. 2010. Nutrient budget and soil nutrient status in greenhouse system. Scientia Agricultura Sinica 43:514-522.

Zhang, X.Y., Y.M. Gao, L. Ye, and J.S. Li. 2011. Present status, problems, and measures on facility horticulture in Ningxia. J. Agr. Sci. 32:53-57.

Zhang, L., L. Gao, L. Zhang, S. Wang, X. Sui, and Z. Zhang. 2012. Alternate furrow irrigation and nitrogen level effects on migration of water and nitrate-nitrogen in soil and root growth of cucumber in solar-greenhouse. Scientia Hort. 138:43-49.

Zhang, X.J., Y. Zhao, X.H. Chen, L.S. Wu, and C.X. Hu. 2007. Effects of application of nitrogen on vegetable yield, nitrogen balance and soil nitrogen accumulation under two years' drip fertigation. Scientia Agricultura Sinica 40:2535-2545.

Zhao, Y., J.H. Luo, X.Q. Chen, X.J. Zhang, and W.L. Zhang. 2012. Greenhouse tomato-cucumber yield and soil $\mathrm{N}$ leaching as affected by reducing $\mathrm{N}$ rate and adding manure: A case study in the Yellow River Irrigation Region China. Nutr. Cycl. Agroecosyst. 94:221-235.

Zhao, M.Q., Y. Shi, X. Chen, and J. Ma. 2011. Soil nitrogen accumulation in different ages of vegetable greenhouses. Procedia Environ. Sci. $8: 21-25$.

Zhou, J.B., Z.J. Chen, X.J. Liu, B.N. Zhai, and D.S. Powlson. 2010. Nitrate accumulation in soil profiles under seasonally open "sunlight greenhouses" in northwest China and potential for leaching loss during summer fallow. Soil Use Mgt. 26:332-339.

Zhou, B., Z.J. Chen, and J.B. Zhou. 2006. Effect of different fertilizer and water managements on the yield and quality of tomatoes and nutrient accumulations in soil cultivated in sunlight greenhouse. J. Northwest Sci.-Tech. Univ. Agr. For. (Nat. Sci. Ed.) 34:58-68.

Zhu, J.H., X.L. Li, P. Christie, and J.L. Li. 2005. Environmental implications of low nitrogen use efficiency in excessively fertilized hot pepper (Capsicum frutescens L.) cropping systems. Agr. Ecosyst. Environ. 111:70-80. 